\title{
Water Stress Revealed Physiological and Biochemical Variations in Taro [Colocasia esculenta (L.) Schott] Varieties/Genotypes
}

\author{
Sanket J. More ${ }^{1 *}$, S. Divya Kumari ${ }^{2}$, J. Suresh Kumar ${ }^{1}$ and V. Ravi ${ }^{1}$ \\ ${ }^{1}$ ICAR-Central Tuber Crops Research Institute, Sreekariyam P.O., Kerala, India \\ ${ }^{2}$ Department of Biochemistry, Emmanuel College, Vazhichal P.O., Kerala, India \\ *Corresponding author
}

\begin{tabular}{|l|}
\hline Ke y w o r d s \\
Variation, \\
Genotypes, Taro, \\
Proline content, \\
$\begin{array}{l}\text { Sree Reshmi, } \\
\text { Tamarakannan }\end{array}$ \\
\hline Article Info \\
\hline $\begin{array}{l}\text { Accepted: } \\
\text { 18 July } 2019 \\
\text { Available Online: } \\
\text { 20 August } 2019\end{array}$ \\
\hline
\end{tabular}

\section{Introduction}

Taro, one of the world's oldest food crops is
thought to be consumed by human being since
9000 years. First domesticated in Southeast
Asia, taro is now spreading across the globe

Taro, one of the world's oldest food crops is
thought to be consumed by human being since
9000 years. First domesticated in Southeast
Asia, taro is now spreading across the globe

Taro, one of the world's oldest food crops is
thought to be consumed by human being since
9000 years. First domesticated in Southeast
Asia, taro is now spreading across the globe

Taro, one of the world's oldest food crops is
thought to be consumed by human being since
9000 years. First domesticated in Southeast
Asia, taro is now spreading across the globe

\section{A B S T R A C T}

Taro [Colocasia esculenta (L.) Schott] is one of the tropical tuber crops hailed as food security crop in tropics especially in developing nations. Tropical tuber crops are famously known for their withstanding capacity under harsh and marginal environments. But the severe reduction has been reported in taro biochemical, physiological parameters and corm yield under water deficit stress in spite of inherent drought tolerance capacity. Meager information is available pertaining to biochemical, physiological variations and tolerance mechanisms under water stress in taro. Full understanding of tolerance mechanisms under water stress in taro is key in developing highly stress-tolerant varieties with improved yield. Keeping this view, the effect of water deficit stress on variation in biochemical and physiological parameters was assessed in seven taro varieties/genotypes. Highly significant differences $(\mathrm{P}<0.001)$ were observed for all varieties/genotypes and parameters selected for the study. As a consequence of water deficit stress, all parameters (except proline content) were greater in varieties/genotypes grown under irrigated conditions as compared to varieties/genotypes grown under water deficit stress. As a defensive mechanism, proline content (Irrigated: 66.36-89.96 $\mu \mathrm{g} \mathrm{g}^{-1}$; Water deficit stress: 200-358.33 $\mu \mathrm{g} \mathrm{g}^{-1}$ ) was found to be augmented in the plants subjected to water deficit stress. Under water deficit stress, significantly higher chlorophyll a $\left(1.23 \mathrm{mg} \mathrm{g}^{-1}\right)$, chlorophyll $\mathrm{b}(0.37$ $\left.\mathrm{mg} \mathrm{g}^{-1}\right)$, total chlorophyll $\left(1.60 \mathrm{mg} \mathrm{g}^{-1}\right)$ and carotenoid content $\left(0.31 \mathrm{mg} \mathrm{g}^{-1}\right)$ were recorded in genotype Jankri, whereas, significantly higher protein $\left(1.10 \mathrm{mg} \mathrm{g}^{-1}\right)$ and proline content (358.33 $\mathrm{mg} \mathrm{g}^{-1}$ ) was found in Sree Reshmi and Tamarakannan, respectively. Pertaining to physiological parameters, significantly higher relative water content $(67.15 \%)$ was exhibited by Telia genotype, whereas, Sree Kiran variety was more drought-tolerant owing to higher chlorophyll stability index (53.67\%) and membrane stability index (45.00\%). and now has become an important crop in tropical and developing nations like SouthEast Asian countries, Pacific Islands, Asia, Africa, Europe and the Caribbean Islands (Rao et al., 2010; Ravi et al., 2019). Taro is one of the only 15 species consisting of 
tubers/corms as edible part out of the 50,000 edible plants growing in the world (More et al., 2019). Taro is an important staple food in many regions of the world, producing 12.13 million tonnes on 1.8 million hectares, with an average yield of $6.73 \mathrm{t} \mathrm{ha}^{-1}$ (FAOSTAT, 2017). Taro is generally cultivated under rainfed, irrigated and flooded pots conditions (Onwueme, 1999, Gananca et al., 2018). Rao et al., (2010) are of the opinion that taro is frequently referred to as an 'orphan crop' because of little attention received from the international agricultural research community. Moreover, less explored genetic diversity of taro makes it vulnerable to a range of biotic and abiotic stresses (Rao et al., 2010, Wairiu et al., 2012, Gananca et al., 2018).

Anthropogenic climate change poses a serious threat to current and future global food production due to the direct effects of changes in mean climatic conditions, increasing risks from extreme weather events, increased atmospheric $\mathrm{CO}_{2} \quad$ concentration and increasing pest damage. Global warming is a well-established fact (More et al., 2017, 2018). Imminent changes in climate are results of various human-made emissions leading to increment in global average temperature due to increased levels of components of greenhouse gases such as carbon dioxide, methane, ozone, nitrous oxide and chlorofluorocarbons (Mall et al., 2006). Most of the warming occurred in the past 35 years, with 17 of the 18 warmest years on record occurring since 2001. As a consequence, 2018 was the warmest year on record. Due to global warming, the planet's average surface temperature has risen about $1.1^{\circ} \mathrm{C}$ since the late $19^{\text {th }}$ century (https://climate.nasa.gov). The Fourth Assessment Report (AR4) of the Intergovernmental Panel on Climate Change (IPCC, 2007) has predicted the rise of a $1-3^{\circ} \mathrm{C}$ rise in mean temperature further depleting the water availability. This report also projected changes in the frequency and severity of extreme climatic events which will have more serious consequences for food production and food insecurity than changes in mean climate alone (Easterling et al., 2007). Extreme climatic stress has a negative impact on crop yields (Deryng et al., 2014). According to world estimates, average yield losses in agricultural crops up to $50 \%$ is mainly due to different abiotic stresses as a result of these changing climatic conditions (Theilert, 2006). Water stress affects the metabolic pathways at every stage of life. Under such circumstances, taro's yield is estimated to reduce by $40 \%$ in the coming 3 decades (Wairiu et al., 2012). Very few information is available regarding the morphological, agronomic, yield and physiological assessment of taro under abiotic stress (Sivan, 1995; Bussell and Bonin, 1998; Manyatsi et al., 2011; Mabhaudhi et al., 2013; El-Zohiri and Abd El-Aal, 2014; Mabhaudhi and Modi, 2015).

Hence, the objective of the present study was to assess the variation in various biochemical and physiological parameters of taro under irrigated and water-deficit stress conditions.

\section{Materials and Methods}

\section{Variety selection and establishment of experimental plots}

Varieties/genotypes were selected based on dry matter parameters and farmers' preference and cormels weighing about 50-75 gm were planted in a Randomized Complete Block Design (RCBD) fashion with the factorial concept (variety $\mathrm{x}$ water regime) in block-I of ICAR-CTCRI during October-2016 to July2017. The experiment consisted of two factors viz., varieties/genotypes (seven) and water regime (two) replicated thrice with 25 plants plot $^{-1}$. Factor-1 consisted of seven varieties/genotypes viz; three varieties i.e., Sree Reshmi, Sree Kiran, Mukthakeshi and 
four genotypes i.e., Telia, Dasheen, Jankri and Tamarakannan and which were cultivated as per the cultivation practices recommended by Ravindran et al., (2013). Factor-2 consisted of two water regimes viz., Irrigated and water deficit stress condition (WDS). WDS condition was created by withdrawing water supply, whereas, plants under irrigated conditions were supplemented with water supply.

\section{Estimation of biochemical parameters}

The total chlorophyll and carotenoid content of the leaves were estimated as per the method suggested by Lichtenthaller (1987). Quantitative measurements for chlorophyll a (Chl-a), chlorophyll b (Chl-b) and carotenoids were determined spectrophotometrically by taking their absorbencies at the following wavelengths respectively; 662, 644 and 445 $\mathrm{nm}$. The protein content of the leaf sample was estimated by Bradford (1966) method by recording absorbance at $595 \mathrm{~nm}$. Proline estimation on the leaves of taro varieties/genotypes under irrigated and WDS conditions was determined by the method reported by Bates et al., (1973). Spectrophotometrically absorbance was recorded at $620 \mathrm{~nm}$ wavelength. Following formula was used to measure proline content.

Proline content $\left(\mu \mathrm{g} \mathrm{g}^{-1}\right)=($ Factor $\mathrm{x}$ A $\mathrm{x}$ volume of sulphosalicylic acid)/ Vol. of sample taken $\mathrm{x}$ W

Where, $\mathrm{W}=$ Weight of leaves, $\mathrm{A}=\mathrm{Absorbance}$ value.

\section{Estimation of physiological parameters}

\section{Relative water content (\%) (RWC)}

RWC was calculated by measuring the fresh weight, dry weight and turgid weight of the known number of leaf disc from the treatment plant. After measuring the fresh weight of the sample, it was submerged in the distilled water for 3 hours and then the turgid weight was taken. The dry weight of the sample was measured after keeping the sample in the oven at $80^{\circ} \mathrm{C}$ for three consecutive days (Pieczynski et al., 2013). The RWC of the treatment was calculated using the following formula:

RWC $(\%)=(\mathrm{FW}-\mathrm{DW}) /(\mathrm{TW}-\mathrm{DW}) \times 100$

Where, FW=fresh weight, DW= dry weight, $\mathrm{TW}=$ turgid weight

\section{Chlorophyll stability index (\%) (CSI)}

Chlorophyll stability index (\%) was measured by exposing leaf sample to a hot water bath at $56^{\circ} \mathrm{C} \pm 1^{\circ} \mathrm{C}$ for 30 minutes, followed by grounding the sample in $100 \mathrm{ml}$ of $80 \%$ acetone. The control sample was kept normal. The absorbance of the filtrate was recorded at 645 and $663 \mathrm{~nm}$ on UV-visible spectrophotometer (Shimadzu-1601) (Agarie et al., 1995). Then, the chlorophyll stability index was calculated by using the formula:

CSI $(\%)=($ Chlorophyll content of boiled sample)/ (Chlorophyll content of normal sample) x 100

\section{Membrane stability index (\%) (MSI)}

The membrane stability index (MSI) was determined according to the method of Deshmukh et al., (1991). $0.5 \mathrm{~g}$ of fresh leaf sample is collected and is washed thoroughly with double distilled water. Then $10 \mathrm{ml}$ double distilled water is added to all the tubes and the tubes are kept in the refrigerator for 24 hours. The tubes are taken after 24 hours and $5 \mathrm{ml}$ water is added and kept for 1 hour at room temperature. Then electrical conductivity is noted. Then the tubes containing leaf samples are heated for 15 minutes at $55^{\circ} \mathrm{C}$ and cooled. Then electrical 
conductivity is measured again. Finally, MSI was determined by using the following formula.

$\operatorname{MSI}(\%)=[1-\mathrm{C} 1 / \mathrm{C} 2] \times 100$

Weather data pertaining to the period of measurement of observations, February 2017June 2017 has been illustrated in figure 1 .

\section{Results and Discussion}

The plant responds to water stress via morphological, physiological and metabolic changes. Such changes are subjected to happen at various developmental stages. However certain growth phases are highly sensitive for soil moisture status that severely hampers the overall crop yield (Toscano et al., 2016). Severe reduction in various biochemical, physiological parameters and taro corm yield has been recorded eventhough it is regarded asa drought-tolerant crop. Keeping this view, this experiment was planned to assess the performance pertaining to various biochemical and physiologicalparameters of seven varieties/genotypes of taro under water stress.

\section{Biochemical parameters}

The Chl-a, Chl-b and total chlorophyll content in taro leaves under irrigated and WDS conditions ranged from 1.28-1.84 and 1.00$1.25 \mathrm{mg} \mathrm{g}^{-1} \mathrm{FW}, 0.34-0.57$ and $0.19-0.37 \mathrm{mg}$ $\mathrm{g}^{-1} \mathrm{FW}$ and 1.70-2.41 and 1.24-1.60 $\mathrm{mg} \mathrm{g}^{-1}$ FW, respectively (Fig. 2, 3, 4). Reduction in the Chl-a, Chl-b and total chlorophyll content in taro leaves under irrigated and WDS conditions ranged from 13.43-32.19\%, 27.78$59.12 \%$, and $16.38-33.61 \%$, respectively. The results of the variance analysis showed that there were significant differences between the taro varieties/genotypes $(\mathrm{P}<0.001)$. Jankri genotype recorded highest Chl-a, Chl-b and total chlorophyll under irrigated (1.84, 0.57 and $2.41 \mathrm{mg} \mathrm{g}^{-1}$, respectively) and WDS conditions (1.25, 0.37 and $1.60 \mathrm{mg} \mathrm{g}^{-1}$, respectively). The total chlorophyll reduction in drought conditions is a consequence of the reduction in relative water content (Makbul et al., 2011). Results are in agreement with Nuwamanya et al., (2014) in cassava, Sakya et al., (2018) in tomato and Ghodke et al., (2018) in onion.

The same trend was observed in case of carotenoid content in taro leaves (Fig. 5). The highest carotenoid content was detected in Jankri genotype under irrigated (0.43-0.61 mg $\left.\mathrm{g}^{-1}\right)$ and WDS (0.19-0.31 $\left.\mathrm{mg} \mathrm{g}^{-1}\right)$ conditions. In this experiment, the content of carotenoids was lower WDS compared to the irrigated conditions. Carotenoid content under WDS condition was found to be reduced by 44.96$58.87 \%$. This was due to the enhancing and inhibiting effects of abiotic stress on individual carotenoids that existed in the plants. The same result was also reported by Norshazila et al., (2017) in pumpkin and Nuwamanya et al., (2014) in cassava.

Overproduction of proline is a widespread response observed in plants experiencing various stresses, in particular, water stress. The determination of this amino acid is therefore very useful to assess the physiological status and more generally to understand stress tolerance in plants. The proline content on the seven varieties/genotypes of taro under irrigated and WDS conditions was extremely diverse, ranged from 66.36-89.96 $\mu \mathrm{g} \mathrm{g}^{-1}$ fresh weight and 200-358.33 $\mu \mathrm{g} \mathrm{g}^{-1}$, respectively (Fig. 6). Proline content in the leaves under WDS condition was elevated up to 2-3 folds as compared to the irrigated condition.The proline content in Tamarakannan genotype was higher than others under both water regimes. This indicates that Tamarakannan genotype attempted to survive in the drought conditions by increasing proline content. 
Plants cope up negative consequences of water stress by accumulating higher proline content which is a measure of osmotic adjustment. Research results reported in this experiment are in agreement with Hamim et al., (2008), Ashraf and Fooland (2007), Ghodke et al., (2018) and Jurekova et al., (2011).

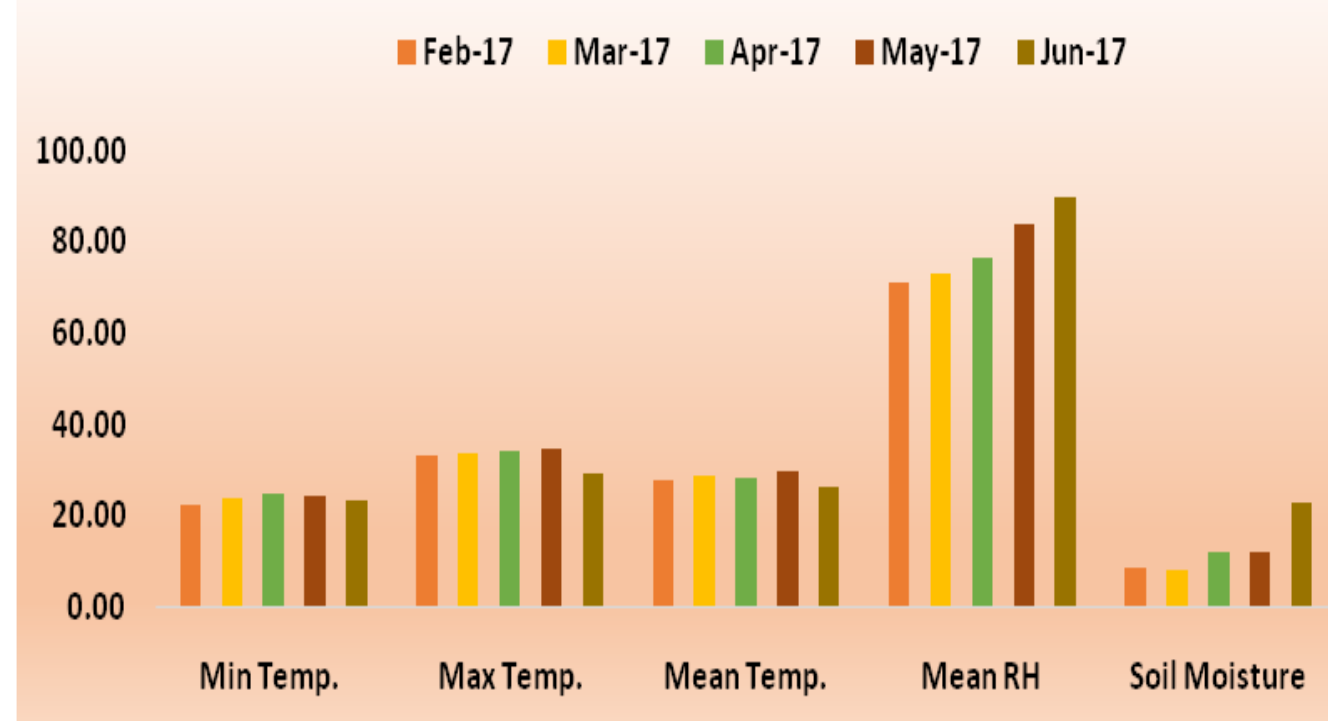

Figure.1 Minimum, maximum and mean temperature $\left({ }^{\circ} \mathrm{C}\right)$, mean relative humidity $(\%)$ and soil moisture (\%) during the period of measurement of observations

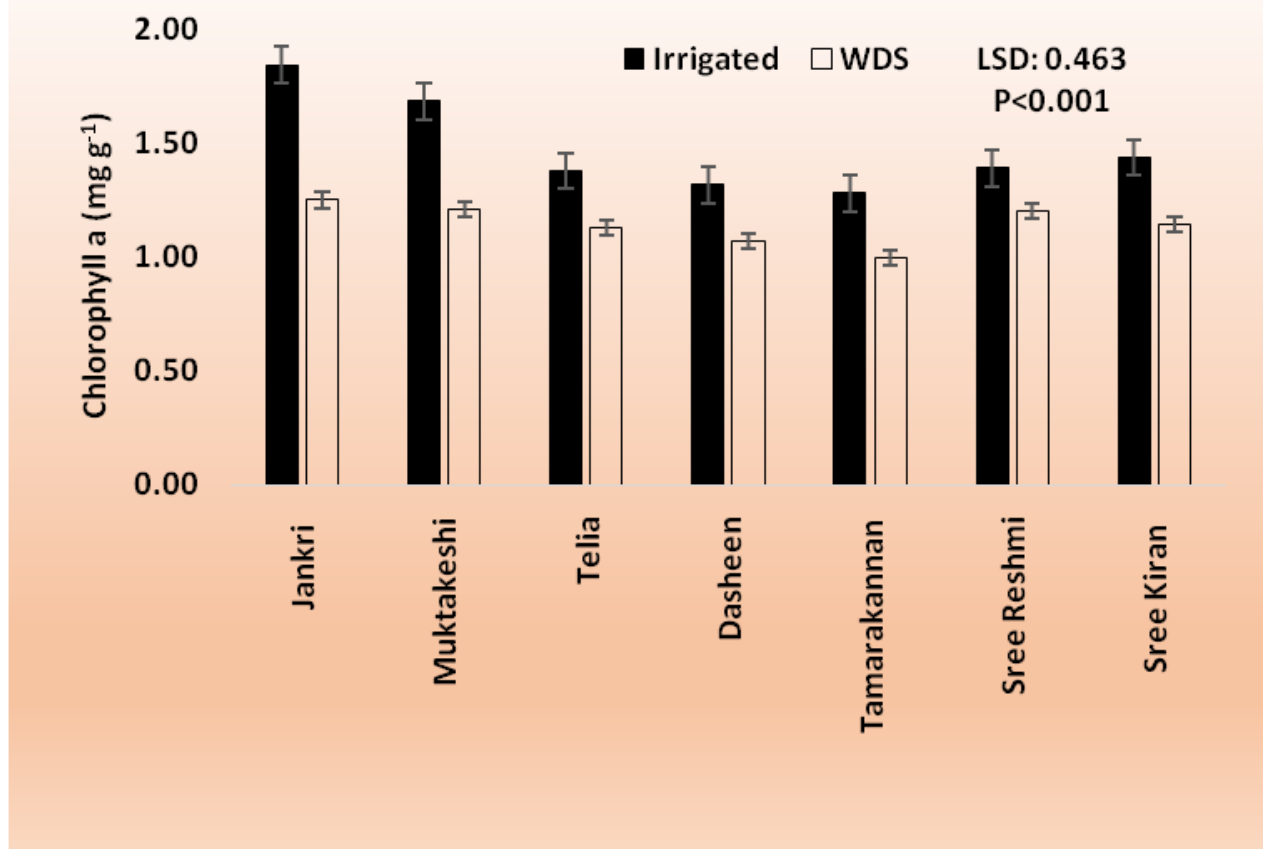

Figure.2 Chlorophyll a content $\left(\mathrm{mg} \mathrm{g}^{-1}\right)$ of taro grown under irrigated and water deficit stress (WDS) conditions. The error bars indicate St. Error. 


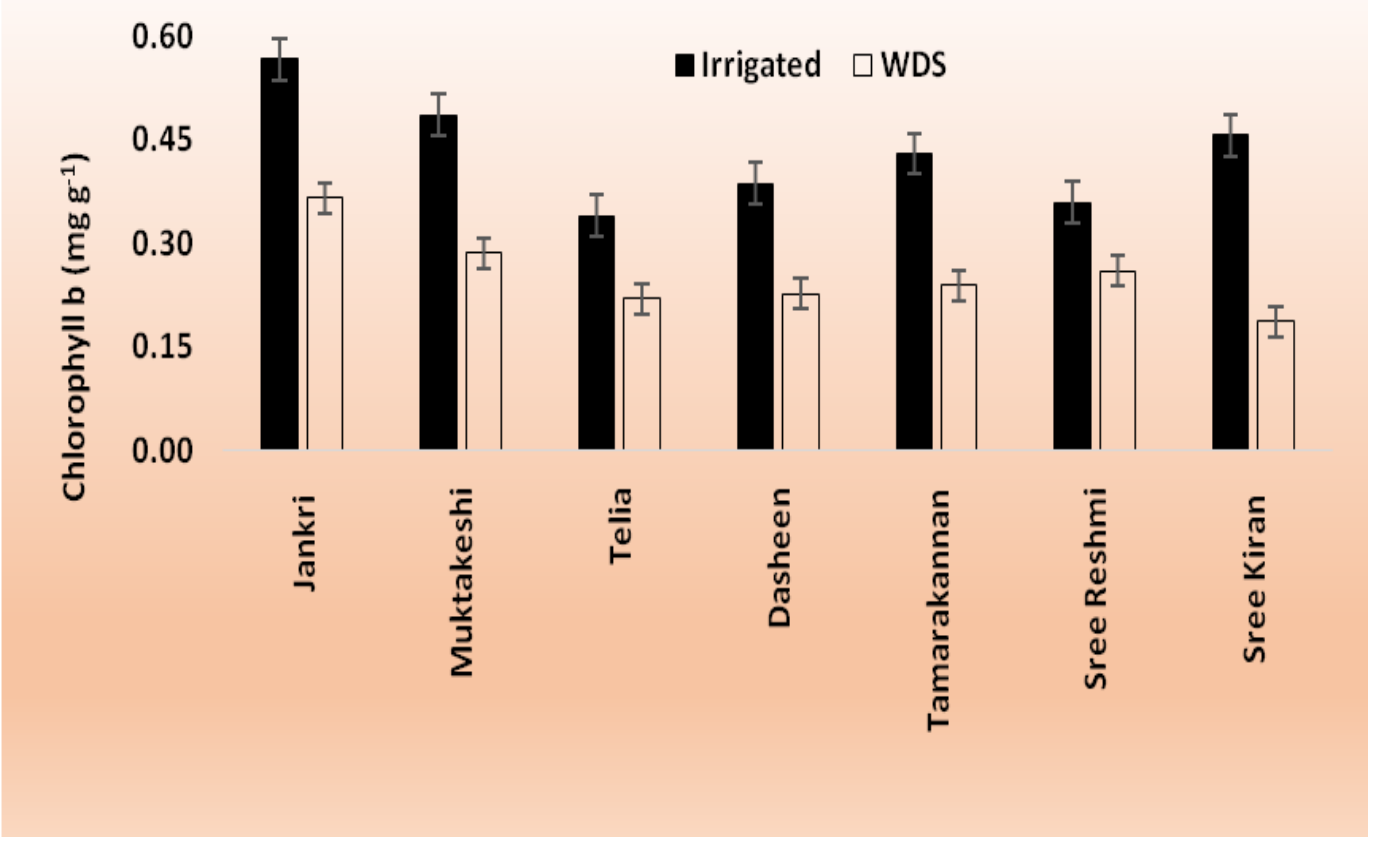

Figure.3 Chlorophyllb content $\left(\mathrm{mg} \mathrm{g}^{-1}\right)$ of taro grown under irrigated and water deficit stress (WDS) conditions. The error bars indicate St. Error.

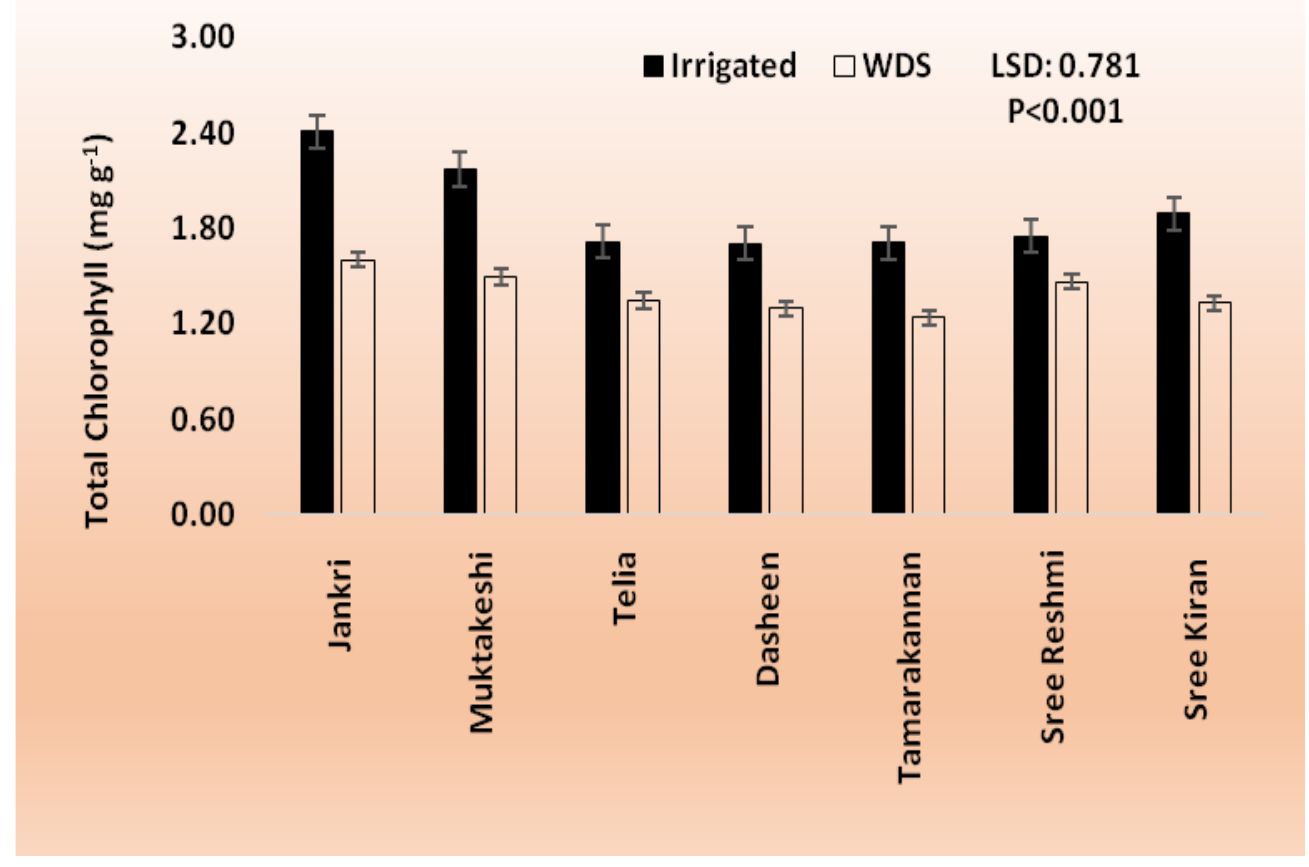

Figure.4 Total chlorophyll content $\left(\mathrm{mg} \mathrm{g}^{-1}\right)$ of taro grown under irrigated and water deficit stress (WDS) conditions. The error bars indicate St. Error. 


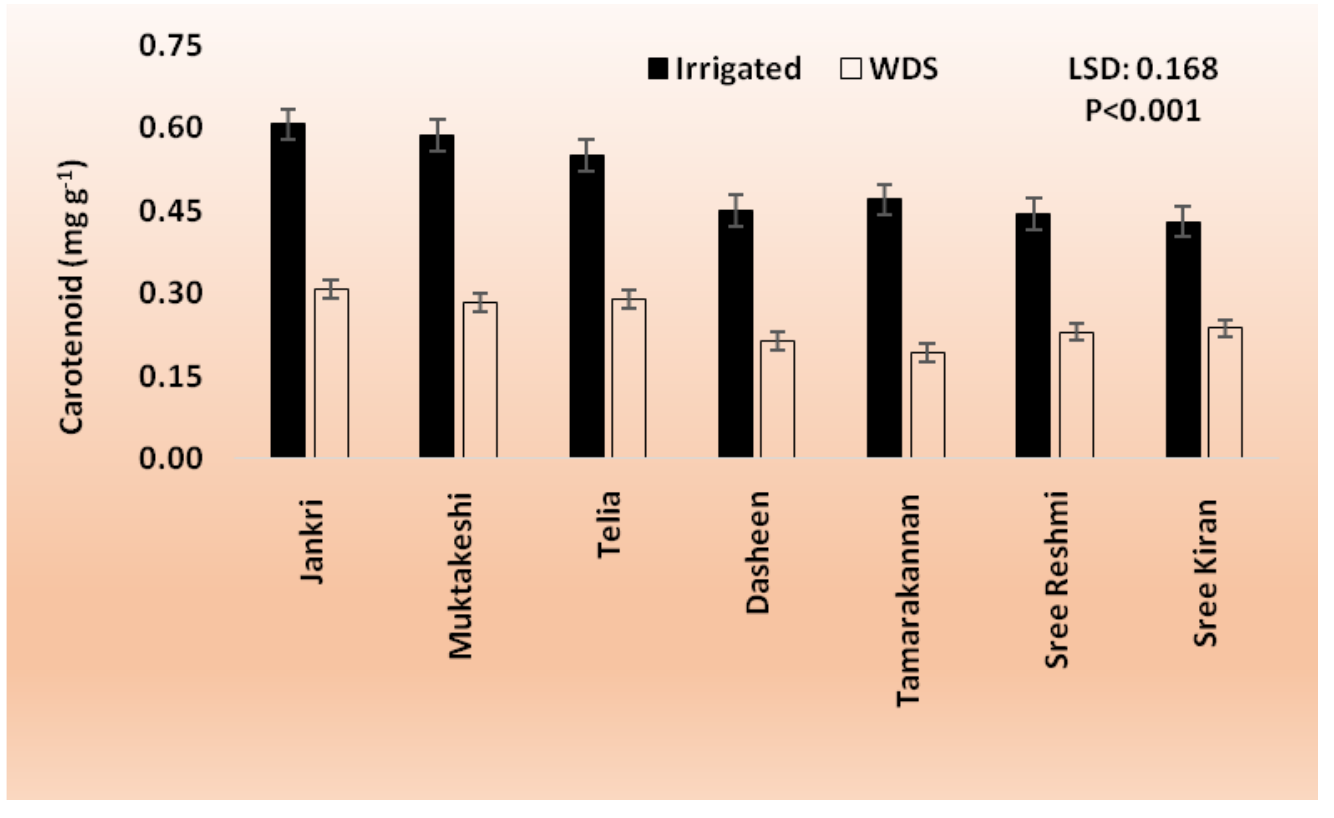

Figure.5 Carotenoid content $\left(\mathrm{mg} \mathrm{g}^{-1}\right)$ of taro grown under irrigated and water deficit stress (WDS) conditions. The error bars indicate St. Error

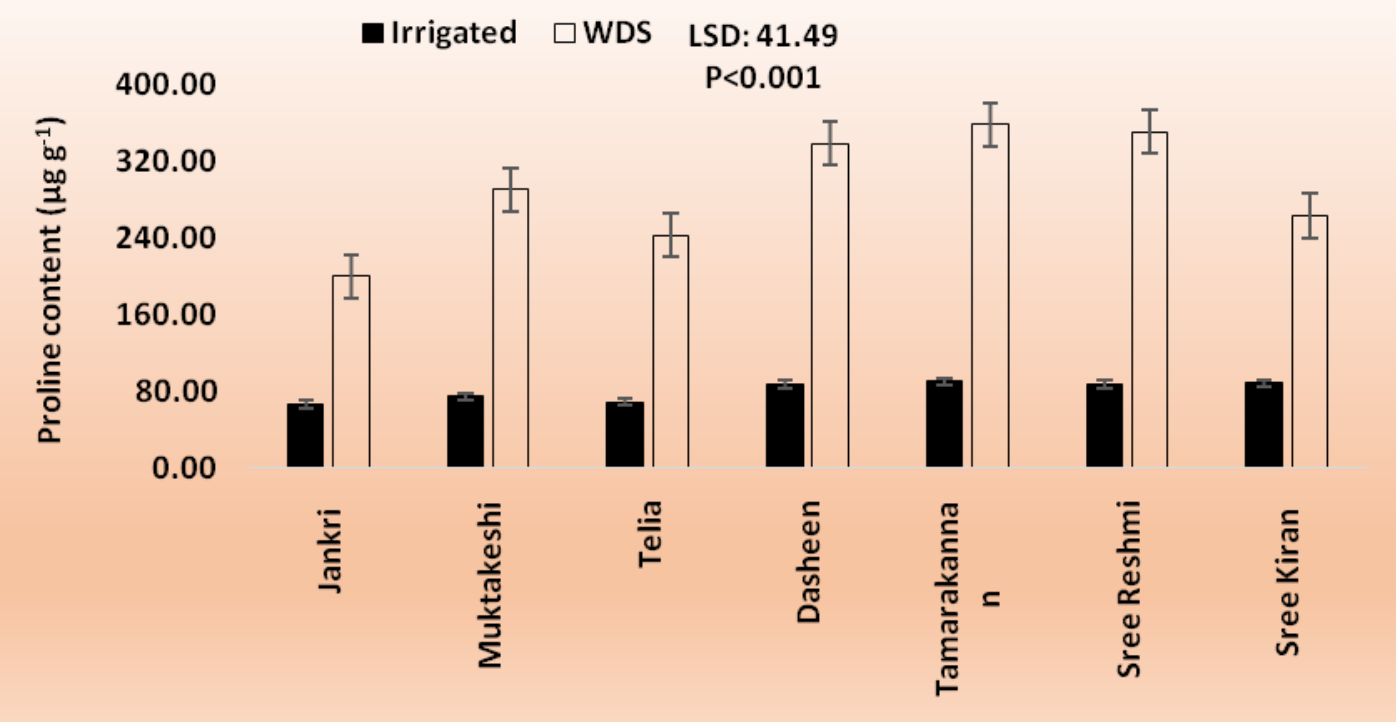

Figure.6 Proline content $\left(\mu \mathrm{g} \mathrm{g}^{-1}\right)$ of taro grown under irrigated and water deficit stress (WDS) conditions. The error bars indicate St. Error. 


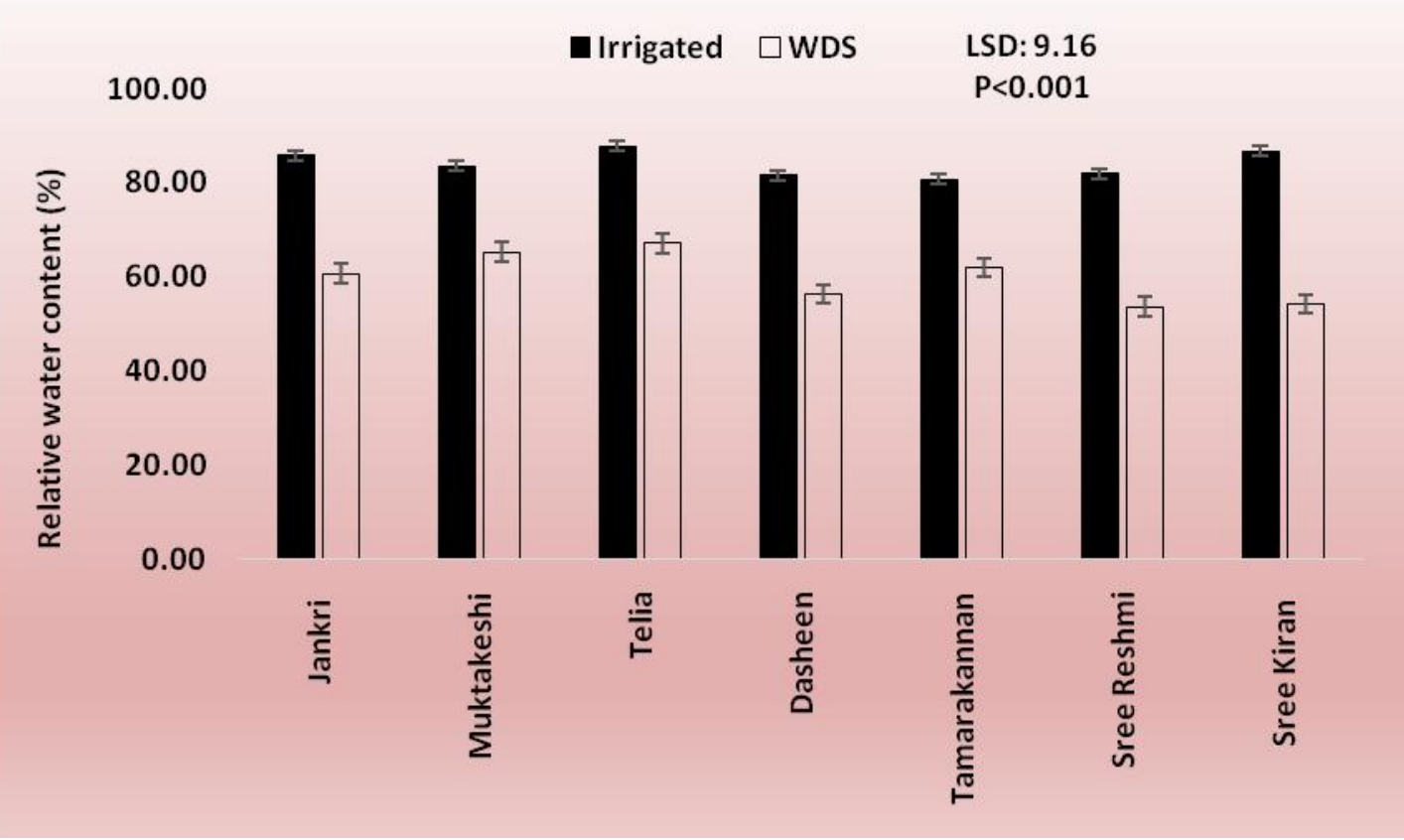

Figure.7 Relative water content (\%) of taro grown under irrigated and water deficit stress (WDS) conditions. The error bars indicate St. Error.

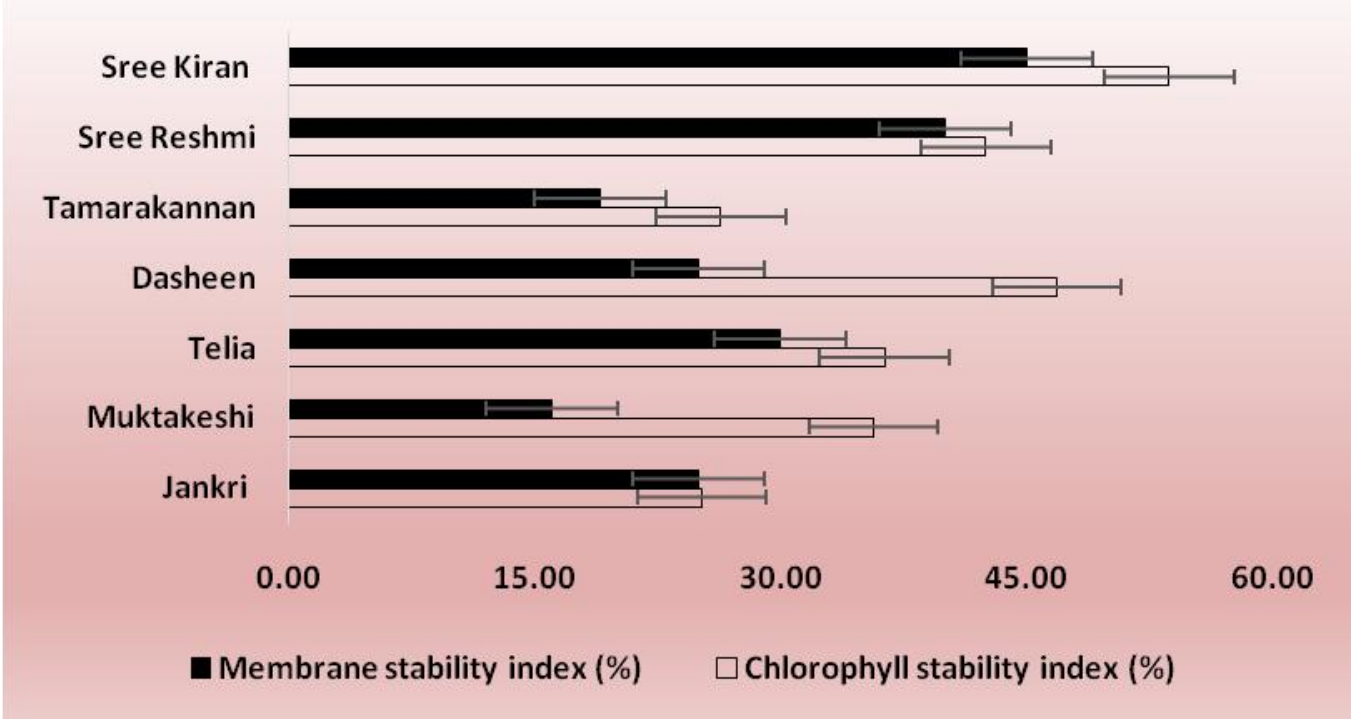

Figure.8 Membrane stability index (\%) and chlorophyll stability index (\%) of taro grown under irrigated and water deficit stress (WDS) conditions. The error bars indicate St. Error. 


\section{Physiological parameters}

Relative water content is considered as one of the most reliable parameter to assess the drought tolerance of crop species. RWC is an indicator of plant water status under various soil type and water regime, irrigation scheduling, crop species, and environmental conditions. Significant differences $(\mathrm{P}<0.001)$ were observed for RWC (Fig. 7). In the present experiment, as a consequence of water stress RWC in plant leaf tissue subjected to WDS ranged between 53.67-67.15\% in comparison to leaf $(80.67-87.83 \%)$ from the irrigated plot. Reduction up to $21-80-37.41 \%$ was observed in RWC content in leaf tissues grown under WDS conditions. Among seven varieties/genotypes, Telia genotype recorded higher RWC under irrigated (87.83\%) as well as WDS (67.15\%) conditions. Several researchers have reported previously that drought stress diminishes plant water status (RWC) in several crops like in maize (Aslam et al., 2015), rice (Todaka et al., 2017) and tomato (Nir et al., 2014). The findings by Munne-Bosch et al., (2003) revealed that 80\% RWC value indicated the good plant water status whereas, plant with $66-68 \%$ RWC as moderately drought tolerant and RWC less that $50 \%$ reflects plant under severe water deficit stress. Even though the reduction in RWC was recorded in Telia genotype under the influence of drought stress but still the plant was able to maintain its plant water potential which showed that it has some adaptive traits and tolerance mechanism that protect the crop under stressful environment. Differences observed for CSI and MSI were statistically at par $(\mathrm{P}<0.001)$ (Fig. 8). Scrutiny of the experimental data revealed that data for chlorophyll stability index and membrane stability index ranged between 25.17-53.67\% and $16.00-45.00 \%$, respectively. Sree Kiran variety recorded highest CSI (53.67\%) and MSI $(45.00 \%)$, respectively. Results are in agreement with Shinde and Laware (2010) in peanut and Almeselmani et al., (2011) in wheat. Relative water content (RWC) and membrane stability index (MSI) are probably the most appropriate measures of plant water status in terms of the physiological consequence of cellular water deficit. The membrane stability index exhibits the extent of damage and explains the ability of the membrane to survive in the drought stress. All the physiological parameters under WDS were reduced significantly as compared to irrigated conditions. The first and the most important effect of drought on the growth of the plant body is the obstructed leaf water budget (Farooq et al., 2010). Results are in agreement with Sakya et al., (2018) in tomato.

\section{References}

Agarie Sakae, Naomi Hanaoka, Fumitake Kubota, Waichi Agata and Peter B. Kaufman. 1995. Measurement of Cell Membrane Stability Evaluated by Electrolyte Leakage as a Drought and Heat Tolerance Test in Rice (Oryza sativa L.). J. Fat. Agr., Kyushu Univ.,40 (1-2): 233-240.

Almeselmani, M., Abdullah, F., Hareri, F., Naaesan, M., Ammar, M. A., Kanbar, O. Z. and Saud, A. A. 2011.Effect of drought on different physiological characters and yield component in different varieties of Syrian durum wheat.J. Agril. Sci.,3: 127-133.

Ashraf, M. and Foolad, M.R. 2007. Roles of glycine betaine and proline in improving plant abiotic stress resistance. Env. Exp. Bot., 59: 206-216.

Aslam, M., Zamir, M.S.I.,Anjum, S.A.,Khan,I. and Tanveer,M. 2015. An Investigation into Morphological and Physiological Approaches to Screen Maize (Zea mays L.) Hybrids for Drought Tolerance. Cereal Research Communications, 43(1): 41-51. DOI: 
10.1556/CRC.2014.0022

Bates, L.S., Waldren, R.P. and Teare, I.D. 1973. Rapid determination of free proline for water stress studies.Plant Soil,39: 205-207.

Bradford, M. M. 1966. A rapid and sensitive method for the quantification of microgram quantities of protein utilizing the principle of protein dye binding. Anal Biochem, 72: 248-254.

Bussell, W.T. and Bonin, M.J. 1998. Effects of high and low watering levels on growth and development of taro. New Zeal. J. Crop Hort., 26:313-317.

Deryng Delphine, Declan Conway, Navin Ramankutty, Jeff Price, Rachel Warren. 2014. Global crop yield response to extreme heat stress under multiple climate change futures. Environ. Res. Lett., 9:1-13. doi:10.1088/17489326/9/3/034011

Deshmukh, P.S., Sairam,R.K. and Shukla,D.S.1991. Measurement of Ion Leakage as a screening technique for drought resistance in wheat genotypes. Indian J. Plant Physiol., XXXIV(I): 8991.

Easterling, W.E., Aggarwal, P.K., Batima, P., Brander, K.M., Erda, L., Howden, S.M., Kirilenko, A., Morton, J., Soussana, J.F., Schmidhuber, J., Tubiello, F.N. 2007. Food, fibre and forest products. Climate Change 2007: Impacts, Adaptation and Vulnerability. Contribution of Working Group II to the Fourth Assessment Report of the Intergovernmental Panel on Climate Change, M.L. Parry, O.F. Canziani,J.P. Palutikof, P.J. van der Linden and C.E. Hanson, Eds., Cambridge University Press, Cambridge, UK. pp. 273-313.

El-Zohiri, S.S.M., Abd El-Aal, A.M.H. 2014. Improve the adverse impacts of water stress on growth, yield and its quality of taro plants by using glycinebetaine, $\mathrm{MgCO}_{3}$ and defoliation under delta conditions. Middle East J. Agric.,3(4):799-814.

FAOSTAT. 2017. FAO Statistical Database. http://faostat.fao.org.

Farooq, M., Wahid, A., Cheema, S.A., Lee, D.J., Aziz, T. 2010. Comparative time course action of foliar applied glycinebetaine, salicylic acid, nitrous oxide, brasinosteroids and spermine in improving drought resistance of rice. $J$. of Agron. and Crop Sci., 196: 336-345.

Gananca Jose, F.T., Jose G.R. Freitas, Humberto G.M. Nobrega, Vanessa Rodrigues, Goncalo Antunes, Carla S.S. Gouveia, Miguel Rodrigues, Hana Chair, Miguel A.A. Pinheiro De Carvalho, Vincent Lebot. 2018. Screening for Drought Tolerance In Thirty Three Taro Cultivars. Not. Bot. Horti. Agrobo, 46(1):65-74. Doi:10.15835/Nbha46110950

Ghodke, P.H., Andhale, P.S.,Gijare, U.M.,Thangasamy, A., Khade, Y.P.,Mahajan,V. and Singh,M. 2018. Physiological and Biochemical Responses in Onion Crop to Drought Stress.Int.J.Curr.Microbiol.App.Sci., 7(1): 20542062.https://doi.org/10.20546/ijcmas.20 18.701 .247

IPCC. 2007. The Physical Science Basis. Contribution of Working Group I to the Fourth Assessment Report of the Intergovernmental Panel on Climate Change. Solomon S, Qin D, Manning M, Chen Z, Marquis M, Averyt KB, Tignor M, Miller HL (Eds.), Cambridge, UK, Cambridge University Press.

Jurekova, Z., Németh-Molnár, K., Paganová, V. 2011. Physiological responses of six tomatoes (Lycopersicon esculentum Mill.) cultivars to water stress.Journa of Horticulture and Forestry, 3: 294-300.

Lichtenthaller, H K. 1987. Chlorophylls and carotenoids: Pigments of photosynthetic 
biomembranes. Methods Enzymol.,148: 350-382.

Mabhaudhi, T. and Modi, A.T. 2015. Drought tolerance of selected South African taro (Colocasia esculenta L. Schott) Landraces. Exp. Agr., 51:451-466.

Mabhaudhi, T., Modi, A.T. and Beletse, Y.G. 2013. Response of taro (Colocasia esculenta L. Schott) landraces to varying water regimes under a rainshelter. Agr. Water Manage., 121: $102-112$.

Makbul, S., Guler, N.S., Durmus, N. and Guven, S. 2011. Changes in anatomical and physiological parameters of soybean under drought stress. Turk. $J$. Bot., 35:369-377.

Hamim, Ashri K., Miftahudin, Triadiati, 2008. Analysis of water status, proline and antioxidant enzymes activity of some soybean tolerant and sensitive drought and wild soybean. Agrivita, 30:201-210.

Mall, R.K., Ranjeet Singh, Akhilesh Gupta, Srinivasan, G. and Rathore, L.S. 2006. Impact of climate change on Indian agriculture: A review. Clim. Chang., 78:445-

478.http://dx.doi.org/10.1007/s10584006-9236-x

Manyatsi, A.M., Mhazo, N., Mkhatshwa, M, Masarirambi, M.T. 2011. Effect of different in-situ water conservation tillage methods on growth and development of taro (Colocasia esculenta L.). Asian J. Agril. Sci., 3: 1118.

More Sanket, J., Ravi, V. and Saravanan, R. 2017. Management of heat stress to enhance growth, photosynthesis and corm yield of elephant foot yam [Amorphophallus paeoniifolius (Dennst.)]. Sci. Agri., 19(2): 47-54. DOI:

10.15192/PSCP.SA.2017.19.2.4754

More Sanket, J., Ravi, V. and Saravanan, R.
2018. Exogenous application of Salicylic acid ameliorates heat stress tolerance in elephant foot yam [Amorphophallus paeoniifolius (Dennst.)] by up-regulating plant growth and photosynthetic activities. In: Proceedings of National Environment and Climate Change Congress (NECCC - 2018), 20-22 March 2018, Directorate of Environment and Climate Change, Govt. of Kerala, Thiruvananthapuram, Kerala.

More Sanket, J., Ravi, V. and Saravanan, R. 2019. Tropical tuber crops. In: Sergio Tonetto de Freitas, Sunil Pareek (Eds.) Postharvest Physiological Disorders in Fruits and Vegetables, CRC Press, Boca Raton. pp. 719-757. https://doi.org/10.1201/b22001

Munne-Bosch, S., Jubany-Mari, T. and Alegre, L. 2003. Enhanced photo- and anti-oxidative protection, and hydrogen peroxide accumulation in droughtstressed Cistusclusii and Cistusalbidus plants. Tree Physiol., 23: 1-12.

Nir, I., Moshelion, M. and Weiss, D. 2014. The Arabidopsis gibberellin methyl transferase 1 suppresses gibberellins activity, reduces whole plant transpiration and promotes drought tolerance in transgenic tomato. Plant Cell Environ., 37(1): 113-123.

Norshazila, S., Othman, R., Jaswir, I. and Yumi Zuhanis, H.H. 2017. Effect of abiotic stress on carotenoids accumulation in pumpkin plants under light and dark conditions. Int. Food Res. J.,24(Suppl): S387-S394.

Nuwamanya Ephraim, Patrick R. Rubaihayo, Ssetumba Mukasa, Samuel Kyamanywa, Joseph F. Hawumba and Yona Baguma. 2014. Biochemical and secondary metabolites changes under moisture and temperature stress in cassava (Manihot esculenta Crantz). Afr. J. Biotechnol.,13(31): 3173-3186. 
DOI: 10.5897/AJB2014.13663

Onwueme, I. 1999. Taro Cultivation in Asia and the Pacific. Rap Publication. 1999/16. Bangkok. FAO.

Pieczynski, M., Marczewski, W., Hennig, J., Dolata, J., Bielewicz, D., Piontek, P., Wyrzykowska, A., Krusiewicz, D., Strzelczyk-Zyta, D., KonopkaPostupolska, D. 2013. Down-regulation of CBP80 gene expression as a strategy to engineer a drought-tolerant potato. Plant Biotechnol. J., 11: 459469.

Rao, V.R., Hunter, D., Eyzaguirre, P.B. and Matthews, P.J. 2010. Ethnobotany and global diversity of taro. In: Rao VR. (Eds). The Global Diversity of Taro: Ethnobotany and Conservation. Bioversity International, Rome.pp. 1-5.

Ravi, V., More, S. J., Saravanan, R., Byju, G., Nedunchezhiyan, M., Devi, A.A. and Nair, K.P. 2019. Potential increase in photosynthetic response of taro (Colocasia esculenta L.) to photon flux density and elevated $\mathrm{CO}_{2}$. J. Environ. Biol., 40(1):111-118.

DOI: 10.22438/jeb/40/1/MRN-786

Ravindran, C.S., Ramanathan, S. and Easwaran, M. 2013. Agro Techniques of Tropical Tuber Crops. ICAR-CTCRI, Kerala, India. pp. 1-32.

Sakya, A.T., Sulistyaningsih, E., Indradewa, D. and Purwanto, B.H. 2018. Physiological characters and tomato yield under drought stress. IOP Conf. Series: Earth and Environmental Science, 200: 012043. doi: 10.1088/1755-1315/200/1/012043
Shinde, B.M. and Laware, S.L. 2010. Effect of drought stress on agronomic and yield contributing characters in groundnut (Arachis hypogaea L.).Asian J. Exp. Biol. Sci., 1:968-971.

Sivan, P. 1995. Drought tolerance and the effect of potassium supply on growth of taro (Colocasia esculenta (L.) Schott) and tannia (Xanthosoma sagittifolium (L.) Schott). PhD Thesis, University of Queensland.

Theilert, W. 2006. A unique product: The story of imidacloprid stress shield. Pflanzenscutz Nachrichten Science Forum Bayer. 59:73-86. https://zembla.vara.nl/pdf/FOLDER\%2 0The_story_of_the_imidacloprid.pdf

Todaka, D., Zhao, Y., Yoshida, T., Kudo, M., Kidokoro, S., Mizoi, J., Kodaira, K.S., Takebayashi, Y., Kojima, M., Sakakibara, H. and Toyooka, K. 2017. Temporal and spatial changes in gene expression, metabolite accumulation and phytohormone content in rice seedlings grown under drought stress conditions. Plant J., 90(1): 61-78.

Toscano, S., Farieri, E., Ferrante, A. and Romano, D. 2016. Physiological and Biochemical Responses in Two Ornamental Shrubs to Drought Stress. Front Plant Sci., 7: 645-645.

Wairiu, M., Murari, L.M. and Lese, V. 2012. Climate Change Implications for Crop Production in Pacific Islands Region. In: Aladjadjiyan, A (Ed). Food Production - Approaches, Challenges and Tasks. InTech, Shangai. pp. 65-86.

\section{How to cite this article:}

Sanket J. More, S. Divya Kumari, J. Suresh Kumar and Ravi, V. 2019. Water Stress Revealed Physiological and Biochemical Variations in Taro [Colocasia esculenta (L.) Schott] Varieties/Genotypes. Int.J.Curr.Microbiol.App.Sci. 8(08): 2242-2253. doi: https://doi.org/10.20546/ijcmas.2019.808.260 